\title{
One Year of COVID-19 in Pregnancy: A National Wide Collaborative Study
}

\section{Um Ano de COVID-19 na Gravidez: Um Estudo Colaborativo Nacional}

\author{
Nadia BORGES CHAREPE $\triangle^{1,2}$, Alexandra QUEIRÓS ${ }^{1,3}$, Maria José ALVES ${ }^{1}$, Fátima SERRANO ${ }^{1,3}$, \\ Catarina FERREIRA4, Mariana GAMITO ${ }^{5}$, Carolina SMET' ${ }^{6}$, Vanessa SILVA ${ }^{7,8}$, Beatriz FÉRIA ${ }^{9}$, Mafalda LARANJO ${ }^{10}$, \\ Inês MARTINS ${ }^{11}$, Márcia VIEIRA-COIMBRA ${ }^{12}$, Maria do Céu ALMEIDA ${ }^{13}$, Catarina SOARES ${ }^{14}$, Fabiana CASTRO $^{15}$, \\ Gisela ALMEIDA ${ }^{16}$, Isabel REIS ${ }^{17}$, Marta BARBOSA ${ }^{18}$, Mariana SANTOS ${ }^{19}$, Marta MELO ${ }^{20}$, Ariana BÁRBARA ${ }^{21}$, \\ Daniela GONÇALVES ${ }^{22,23}$, Mariline OLIVEIRA ${ }^{24}$, Paula PINHEIRO ${ }^{25}$, Maria de Fátima FAUSTINO ${ }^{26}$, Andreia OLIVEIRA ${ }^{27}$, \\ Helena CANHÃO 2,28 , Ana CAMPOS ${ }^{29}$ \\ Acta Med Port 2022 May;35(5):357-366 - https://doi.org/10.20344/amp.16574
}

\section{ABSTRACT}

Introduction: Even though the risk of COVID-19 in pregnancy may be increased, large-scale studies are needed to better understand the impact of the infection in this population. The aim of this study is to describe obstetric complications and the rate of vertical transmission in pregnant women with SARS-CoV-2 infection.

Material and Methods: Detected cases of SARS-CoV-2 infection in pregnancy were registered in Portuguese hospitals by obstetricians. Epidemiological, pregnancy and childbirth data were collected.

Results: There were 630 positive cases in 23 Portuguese maternity hospitals, most at term (87.9\%) and asymptomatic (62.9\%). The most frequent maternal comorbidity was obesity. The rates of preterm birth and small-to-gestational-age were $12.1 \%$ and $9.9 \%$, respectively. In the third trimester, $2.9 \%$ of pregnant women required respiratory support. There were eight cases $(1.5 \%)$ of fetal death, including two cases of vertical transmission. There were five cases of postpartum respiratory degradation, but no maternal deaths were recorded. The caesarean section rate was higher in the first than in the second wave (68.5\% vs $31.5 \%)$. RT-PCR SARS-CoV-2 positivity among newborns was $1.3 \%$.

Conclusion: SARS-Cov-2 infection in pregnancy may carry increased risks for both pregnant women and the fetuses. Individualized surveillance and the prophylaxis of this population with vaccination. is recommended in these cases.

Keywords: COVID-19; Infant, Newborn; Infectious Disease Transmission, Vertical; Pregnancy; SARS-CoV-2; Vertical Transmission

\section{RESUMO}

Introdução: Apesar do risco da COVID-19 na gravidez poder ser acrescido, são necessários estudos em larga escala para o melhor conhecimento do impacto desta infeção nesta população. O objetivo deste estudo é descrever as complicações obstétricas e a taxa de transmissão vertical em grávidas com infeção a SARS-CoV-2.

Material e Métodos: Os casos conhecidos de infeção por SARS-CoV-2 na gravidez foram registados nos hospitais portugueses por

1. Serviço de Medicina Materno-fetal. Maternidade Dr. Alfredo da Costa. Centro Hospitalar de Lisboa Central. Lisboa. Portugal.

2. Comprehensive Health Research Centre. NOVA Medical School. Lisboa. Portugal.

3. Departmento de Obstetrícia e Ginecologia. Universidade Nova de Lisboa. Faculdade de Ciências Medicas. Lisboa. Portugal.

4. Serviço de Ginecologia e Obstetrícia. Hospital Professor Doutor Fernando Fonseca. Amadora. Portugal.

5. Serviço de Ginecologia e Obstetrícia. Hospital Beatriz Ângelo. Loures. Portugal.

6. Serviço de Ginecologia e Obstetrícia. Hospital de São Francisco Xavier. Centro Hospitalar de Lisboa Ocidental. Lisboa. Portugal.

7. Serviço de Ginecologia e Obstetrícia. Hospital da Senhora da Oliveira. Guimarães. Portugal.

8. Instituto de Investigação em Ciências da Vida e Saúde. Escola de Medicina. Universidade do Minho. Braga. Portugal .

9. Serviço de Ginecologia e Obstetrícia. Hospital Garcia de Orta. Almada. Portugal.

10. Serviço de Ginecologia e Obstetrícia. Unidade Local de Saúde de Matosinhos. Senhora da Hora. Portugal.

11. Departamento de Obstetrícia, Ginecologia e Medicina da Reprodução. Hospital de Santa Maria. Centro Hospitalar e Universitário Lisboa Norte. Lisboa. Portugal

12. Serviço de Ginecologia e Obstetrícia. Centro Hospitalar Tondela/Viseu. Viseu. Portugal.

13. Serviço de Ginecologia e Obstetrícia. Centro Hospitalar e Universitário de Coimbra. Coimbra. Portugal.

14. Serviço de Ginecologia e Obstetrícia. Centro Hospitalar do Oeste. Torres Vedras. Portugal.

15. Serviço de Ginecologia e Obstetrícia. Centro Hospitalar Tâmega e Sousa. Amarante. Portugal.

16. Serviço de Ginecologia e Obstetrícia. Centro Hospitalar de Setúbal. Setúbal. Portugal.

17. Serviço de Ginecologia e Obstetrícia. Hospital de Braga. Braga. Portugal.

18. Serviço de Ginecologia e Obstetrícia. Centro Hospitalar de Vila Nova de Gaia/Espinho. Gaia. Portugal.

19. Serviço de Ginecologia e Obstetrícia. Centro Hospitalar do Algarve. Faro. Portugal.

20. Serviço de Ginecologia e Obstetrícia. Hospital de Vila Franca de Xira. Vila Franca de Xira. Portugal.

21. Serviço de Ginecologia e Obstetrícia. Hospital do Espírito Santo. Évora. Portugal.

22. Serviço de Ginecologia e Obstetrícia. Centro Hospitalar Universitário do Porto. Porto. Portugal.

23. Serviço de Ginecologia e Obstetrícia. Centro Materno-Infantil do Norte Dr Albino Aroso. Porto. Portugal.

24. Serviço de Ginecologia e Obstetricia. Hospital Distrital de Santarém. Santarém. Portugal.

25. Serviço de Ginecologia e Obstetrícia. Unidade Local de Saúde do Alto Minho. Viana do Castelo. Portugal.

26. Serviço de Ginecologia e Obstetrícia. Hospital Lusíadas. Lisboa. Portugal.

27. Serviço de Ginecologia e Obstetrícia. Centro Hospitalar do Médio Ave. Santo Tirso. Portugal.

28. Serviço de Reumatologia. Centro Hospitalar e Universitário de Lisboa Central. Lisboa. Portugal.

29. Direção-Geral da Saúde. Lisboa. Portugal.

$\triangle$ Autor correspondente: Nadia Borges Charepe. nadia.b.charepe@edu.nms.unl.pt

Recebido/Received: 17/05/2021 - Aceite/Accepted: 27/10/2021 - Publicado Online/Published Online: 11/02/2022 - Publicado/Published: 02/05/2022 Copyright $\odot$ Ordem dos Médicos 2022 
obstetras. Foram recolhidos dados epidemiológicos, da gravidez e do parto.

Resultados: Registaram-se 630 casos positivos em 23 maternidades portuguesas, a maioria no termo (87,9\%) e assintomática $(62,9 \%)$. A comorbilidade materna mais frequente foi a obesidade. A taxa de parto pré-termo e de leves para a idade gestacional foi de $12,1 \%$ e $9,9 \%$, respectivamente. No terceiro trimestre, 2,9\% das grávidas necessitaram de suporte respiratório. Verificou-se uma taxa de $1,5 \%$ de morte fetal, incluindo dois casos de transmissão vertical. Houve cinco casos de degradação respiratória no pós-parto, mas sem mortes maternas registadas. A taxa de cesarianas foi mais elevada na primeira do que na segunda vaga $(68,5 \%$ vs $31,5 \%)$. A positividade do RT-PCR SARS-CoV-2 entre os recém-nascidos foi de $1,3 \%$.

Conclusão: A infeção pelo SARS-Cov-2 na gravidez pode acarretar riscos aumentados para as grávidas e fetos. Recomenda-se uma vigilância individualizada nestes casos e a profilaxia desta população com a vacinação.

Palavras-chave: COVID-19; Gravidez; Recém-Nascido; SARS-CoV-2; Transmissão Vertical de Doenças Infecciosas

\section{INTRODUCTION}

By the end of December 2019, a new virus was discovered in Wuhan (Hubei, China): the severe acute respiratory syndrome coronavirus 2 (SARS-CoV-2), responsible for the pandemic disease that is now known as COVID-19. ${ }^{1}$

In pregnant patients COVID-19 raises multiple concerns, as other types of coronaviruses have frequently been associated with adverse outcomes. ${ }^{2}$

Pregnancy is a state of immune tolerance and immunosuppression, also accompanied by several physiologic pulmonary changes; therefore COVID-19 can lead to unpredictable maternal and fetal consequences. ${ }^{3}$

The scientific evidence base of the impact of SARSCoV-2 on pregnancy is still scarce. The consequences of this infection remain uncertain, especially in terms of vertical transmission, miscarriage, fetal malformations, preterm labour and other adverse maternal and fetal outcomes.

A published study from Iran reported that among nine pregnant women with severe disease, seven died during the second or third trimester. ${ }^{4}$ In Mexico, there was a report of seven maternal deaths in 308 pregnant women with COVID-19. In most cases these women were healthy, but the incidence of diabetes and obesity was high. ${ }^{5} \mathrm{~A}$ maternal death was reported in the UK, due to thrombotic complications in a 29-year-old pregnant woman with other comorbidities (uncontrolled diabetes and obesity). ${ }^{6}$

A meta-analysis of 2567 pregnancies concluded that maternal death occurred in $0.9 \%$ of reported cases $(n=43)$ and maternal intensive care unit (ICU) admission was required in $7.0 \%$, with a $3.4 \%$ rate of invasive ventilation. The risk of iatrogenic preterm birth and caesarean delivery was increased. ${ }^{7}$

A recent study reveals that in two registries, PAN-COVID and AAP SONPM, including 4004 women, maternal death occurred in $0.5 \%$ and $0.2 \%$, respectively; early neonatal death in $0.2 \%$ and $0.3 \%$, respectively; and stillbirth in $0.50 \%$ and $0.65 \%$ of women, respectively. Overall, delivery was pre-term in $12.0 \%{ }^{8}$

Maternal complications in the postpartum period were also reported, with clinical worsening in $13 \%$ of cases. ${ }^{9}$

Recently, placental infection by SARS-CoV-2 was described: one case on a second trimester miscarriage, two cases of SARS-CoV-2 in the placental fetal side and one case associated with severe early-onset pre-eclampsia. SARS-CoV-2 RNA detection on biological products on a neonate presenting with neurological compromise was also documented. ${ }^{10-13}$
Although vertical transmission is possible, it seems to be uncommon and the prognosis of SARS-CoV-2 infection in neonates is usually good. ${ }^{14}$

Definition of vertical transmission is controversial, due to limitations in specificity and sensitivity in diagnostic tests in use. It has been postulated that vertical transmission can be defined as a positive RT- PCR in neonate or cord blood at 12 hours of delivery or if stillbirth occurred and SARS-CoV-2 is detected in fetal tissues..$^{15}$

Placental histopathology has demonstrated increased fetal underperfusion and thrombosis in fetal vessels that can have clinical implications when infection occurs in early pregnancy. ${ }^{8}$

Pregnancy, especially in the third trimester, increases the risk of severe COVID-19; and is considered the most vulnerable period. ${ }^{16}$

To date, five of the new strains of the COVID-19 virus are present worldwide: the alpha, beta, gamma, delta and omicron variants. The delta variant was associated with more severe disease and increased transmissibility. Recently, omicron variant emerged but more studies to access the impact of this new variant are needed. ${ }^{17-20}$

More studies are required about the implications of these variants, namely in pregnancy.

In Portugal, universal screening has been advocated during hospital admission in most institutions, especially due to the substantial number of asymptomatic cases and their risk of contagion to the neonate..$^{21,22}$ In Portugal, the first COVID-19 case in pregnancy was described by Lyra et al, in March 2020, in a healthy woman with a term pregnancy that tested positive for COVID-19 on the day of labour induction. $^{2}$

Moreover, Dória et al, described the first case series of women with SARS-CoV-2 infection in northern Portugal through systematic screening in this population. ${ }^{23}$

This original work reflects the first three waves of the COVID-19 pandemic in Portugal. At the moment we are facing the fifth wave, and the dominant variant is omicron.

The aim of this study is to describe the epidemiological, clinical characteristics, obstetric outcomes and vertical transmission in pregnant women that have tested positive for SARS-CoV-2 in Portugal.

\section{MATERIAL AND METHODS}

A case series of 630 pregnant women with a confirmed positive test for SARS-CoV-2 between March 24, 2020 
and March 03, 2021 was studied. Data were collected in 23 Portuguese maternity hospitals. Pregnant women were tested during hospital admission using nasopharyngeal/ oropharyngeal swabs for SARS-CoV-2 RT PCR as part of a universal testing policy and whenever symptoms occurred. This multicentre prospective study is registered as COVID\&PREG on Clinical trials platform (ClinicalTrials.gov: NCT04416373).

Maternal demographic data, COVID-19 related data (symptoms, diagnostic tests, pharmaceutical treatments, and gestational age at SARS-CoV-2 confirmed infection), pregnancy outcomes, neonate RT PCR results and breastfeeding strategies were evaluated (Tables 1 and 2). Clinical data was prospectively collected either through a computer assisted questionnaire, from examination of electronic health records, or through linkage to the hospital's electronic databases by experienced obstetricians. Birth weight was classified using INTERGROWTH-2 $1^{\text {st }}$ and Birthweight standard for the Portuguese population calculator. ${ }^{24,25}$

Continuous variables were expressed as means, standard deviation and range and categorical variables were shown as numbers and percentages. We compared continuous data by using two-tailed Student's t-test, and categorical data by Fisher's exact test. We used IBM SPSS version 23 (Chicago,IL ,USA). P-values < 0.05 were considered significant and Odds Ratio and confidence intervals were calculated.

This study was reviewed and approved by the local ethics committee as per principles embodied in the Declaration of Helsinki.

Table 1 - Demographics and baseline characteristics in pregnant women

\begin{tabular}{|c|c|}
\hline Characteristics & $\mathbf{N}^{\circ}(\%)$ of women $(n=630)$ \\
\hline Maternal age, in years, Mean \pm SD (Range) & $30.0 \pm 5.94(17-46)$ \\
\hline \multicolumn{2}{|l|}{ Ethnicity: } \\
\hline Black, Asian or minority ethnic & $251(39.8 \%)$ \\
\hline Caucasian & $360(58.9 \%)$ \\
\hline Missing & $19(3.0 \%)$ \\
\hline Twin pregnancy & $4(0.6 \%)$ \\
\hline Single & $616(97.7 \%)$ \\
\hline BMI $\left(\mathrm{kg} / \mathrm{m}^{2}\right)$, Mean \pm SD (Range) & $27.0 \pm 5.9(16-54)$ \\
\hline Missing & $185(29.4 \%)$ \\
\hline Obesity I/II/III & $127(27.8 \%)$ \\
\hline Overweight & $134(29.3 \%)$ \\
\hline Underweight & $12(2.6 \%)$ \\
\hline \multicolumn{2}{|l|}{ Parity } \\
\hline Nulliparous, n (\%) & $230(36.5 \%)$ \\
\hline Multiparous, n (\%) & $400(63.5 \%)$ \\
\hline Smoking habits & $36(5.7 \%)$ \\
\hline \multicolumn{2}{|l|}{ Comorbid conditions } \\
\hline Present & $268(42.5 \%)$ \\
\hline Obesity & $127(27.8 \%)$ \\
\hline Anaemia & $25(4.0 \%)$ \\
\hline Chronic hypertension & $27(4.3 \%)$ \\
\hline Other cardiovascular disorders & $5(0.8 \%)$ \\
\hline Thyroid disorders & $24(3.8 \%)$ \\
\hline Auto immune disorders & $7(1.1 \%)$ \\
\hline Hepatitis B infection & $7(1.1 \%)$ \\
\hline HIV infection, HIV 1 and 2 & $6(1.0 \%)$ \\
\hline Psychiatric disorders & $9(1.4 \%)$ \\
\hline Asthma & $18(2.9 \%)$ \\
\hline Consumption of illegal drugs & $2(0.3 \%)$ \\
\hline Gastric bypass & $2(0.3 \%)$ \\
\hline Chronic renal disease & $3(0.5 \%)$ \\
\hline Dyslipidemia & $3(0.5 \%)$ \\
\hline Diabetes mellitus & $8(1.3 \%)$ \\
\hline Epilepsy & $3(0.5 \%)$ \\
\hline Genetic disorders & $6(1.0 \%)$ \\
\hline \multicolumn{2}{|l|}{ Gestational age at SARS-CoV-2 detection } \\
\hline$<14$ weeks & $35(5.6 \%)$ \\
\hline $14-23$ weeks & $73(11.6 \%)$ \\
\hline 24 - 32 weeks & $75(11.9 \%)$ \\
\hline 33 - 35 weeks & $67(10.6 \%)$ \\
\hline$\geq 36$ weeks & $380(60.3 \%)$ \\
\hline
\end{tabular}

BMI: body mass index; HIV: human immunodeficiency virus; SD: standard deviation 
Table 2 - Obstetric and neonatal outcomes of COVID-19

\begin{tabular}{|c|c|}
\hline Obstetric outcomes & Values $\mathbf{N}^{\circ}(\%)$ of women $(n=630)$ \\
\hline First trimester loss* & $14(2.2 \%)$ \\
\hline Late loss $(20-22 \text { weeks })^{* *}$ & $3(0.5 \%)$ \\
\hline Abortion on request $<24$ weeks & $3(0.5 \%)$ \\
\hline Preterm birth & $64(12.1 \%)$ \\
\hline $24-27$ weeks & $4(0.6 \%)$ \\
\hline 28 - 31 weeks & $6(1.0 \%)$ \\
\hline 32 - 36 weeks & $54(8.6 \%)$ \\
\hline At term & $463(87.9 \%)$ \\
\hline Ongoing pregnancy & $83(13.2 \%)$ \\
\hline Complications in completed pregnancies & $\mathbf{N}^{\circ}(\%)$ of women $(n=527)$ \\
\hline Present & $238(45.2 \%)$ \\
\hline Gestational diabetes & $80(15.2 \%)$ \\
\hline PPROM & $8(1.5 \%)$ \\
\hline Anaemia/Iron replacement & $12(2.3 \%)$ \\
\hline Threatened preterm labour & $14(2.6 \%)$ \\
\hline Fetal growth restriction & $23(4.4 \%)$ \\
\hline Chorioamnionitis suspicion & $11(2.1 \%)$ \\
\hline Fetal malformations & $9(1.7 \%)$ \\
\hline Intrahepatic cholestasis of pregnancy & $13(2.5 \%)$ \\
\hline Pre-eclampsia/ HELLP & $10(1.9 \%)$ \\
\hline Gestational hypertension & $2(0.3 \%)$ \\
\hline Placenta previa & $5(0.9 \%)$ \\
\hline Oligohydramnios & $2(0.4 \%)$ \\
\hline Pyeolonephritis & $2(0.4 \%)$ \\
\hline Hyperemesis gravidarum & $5(0.9 \%)$ \\
\hline Hydramnios (no diabetes) & $2(0.4 \%)$ \\
\hline First and second trimester bleeding & $2(0.4 \%)$ \\
\hline Stillbirth & $8(1.5 \%)$ \\
\hline Respiratory support & $15(2.9 \%)$ \\
\hline Mode of delivery & $\mathbf{N}^{\circ}(\%)$ of women $(n=527)$ \\
\hline Eutocic & $229(43.5 \%)$ \\
\hline Vacuum assisted delivery & $62(11.8 \%)$ \\
\hline Forceps delivery & $15(2.8 \%)$ \\
\hline Caesarean section and causes: & $221(41.9 \%)$ \\
\hline Fetal distress & $63(28.5 \%)$ \\
\hline Maternal disease in & $51(23.1 \%)$ \\
\hline Arrested labour in & $62(28.1 \%)$ \\
\hline Anomalous fetal presentation & $20(9.1 \%)$ \\
\hline Other fetal cause & $16(7.7 \%)$ \\
\hline Placenta previa & $2(0.9 \%)$ \\
\hline Fetopelvic disproportion & $6(2.7 \%)$ \\
\hline Induction failure & $1(0.9 \%)$ \\
\hline Maternal deaths & none \\
\hline Neonatal outcomes & $\mathbf{N}^{\circ}(\%) \mathbf{n}=\mathbf{5 3 5}$ (8 multiple pregnancies) \\
\hline Birth weight at term, grams, mean \pm SD (range) & $3102 \pm 622(400-4805)$ \\
\hline \multicolumn{2}{|l|}{ Gender: } \\
\hline Female & $258(48.2 \%)$ \\
\hline Male & $277(51.8 \%)$ \\
\hline $\operatorname{SGA}\left(<10^{\text {th }}\right)$ & $74(13.8 \%)$ \\
\hline AGA & $431(80.5 \%)$ \\
\hline $\operatorname{LGA}\left(>90^{\text {th }}\right)$ & $30(5.6 \%)$ \\
\hline 5-minute Apgar score $\leq 7$ (includes 30 preterm) & $4(0.8 \%)$ \\
\hline neonatal death $<7$ days & $3(0.6 \%)$ \\
\hline SARS-CoV-2 RT-PCR positive test (liveborn infants only) & $7(1.3 \%)$ \\
\hline Fetal inflammatory response syndrome associated with maternal SARS-CoV-2 infection & $1(0.2 \%)$ \\
\hline Mother-Newborn isolation & $27(5.1 \%)$ \\
\hline Breastfeeding & $500(93.0 \%)$ \\
\hline
\end{tabular}

SD: standard deviation; SGA: small for gestational age; AGA: adequate for gestational age; LGA: large for gestational age

*: one due to parvovirus infection, two of twin-twin transfusion syndrome (TTTS) and one molar pregnancy; **: three late miscarriages occurred, two of them at 21 weeks and another at 20 weeks in a twin pregnancy complicated with PPROM and chorioamnionitis in a multiparous woman with a history of a previous miscarriage. 


\section{RESULTS}

Our study reports 630 cases of SARS-CoV-2 infection during pregnancy and 527 deliveries at the time of this study.

The mean maternal age was $30.0 \pm 5.94$ years (range 17-46). Most women were multiparous (63.5\%) and of European origin in $58.9 \%(360 / 611)$ (Table 1$)$.

Most pregnant women were diagnosed after 36 weeks of gestation, representing $60.3 \%$ of cases.

The median interval from the first positive RT-PCR for SARS-CoV-2 to delivery was $2.0 \pm 40.17$ days $[\mathrm{IQR}]=19$. Although no comorbidities were found in $57.5 \%$ (362/630) of women, $27.8 \%$ had obesity (127/457). Most of them $(94.3 \%)$ reported no smoking habits (Table 1 ).

Known contact with someone infected with SARSCoV-2 was documented in only $36.8 \%$ of cases (232/630). The majority were asymptomatic, representing $62.9 \%$ (396/630) of cases. The most frequently reported symptoms were cough $17.5 \%$ (110/630), fever $12.5 \%$ (79/630), anosmia $10.8 \%$ (68/630) and headache 10.3\% (65/630). Myalgia and dyspnoea were present in $8.4 \%$ (53/630) and $4.4 \%(28 / 630)$ respectively (Fig. 1). During the post-partum period, there was one case of asthma exacerbation and four cases of severe respiratory disease, with three of them requiring ICU admission.

Hospital admission due to COVID-19 was required in $2.9 \%$ of the cases $(18 / 630)$, of which ten women were admitted to an ICU. In this group, all pregnant women received supportive treatment; the prescribing of azithromycin was limited to eight cases, dexamethasone and hydroxychloroquine to four and one case respectively. Imaging tests were performed in $5.4 \%$ (34/630) of women, and in $2.9 \%$
(18/630) pneumonia was diagnosed. Obesity, hypertension, and dyslipidaemia were the comorbidities found in patients admitted to the Intensive Care Unit (ICU) and there were six women previously healthy. No maternal deaths were registered in this series.

In terms of respiratory support, 15 women required oxygen therapy; one received non-invasive ventilation and two required invasive ventilation (Table 3 ).

Respiratory support was used in $66.7 \%(12 / 18)$ during the late third trimester versus $33.3 \%(6 / 18)$ before 33 weeks.

\section{Pregnancy outcomes}

Delivery occurred in 527 cases, 83 had ongoing pregnancies at the time of this analysis and there were 20 cases of pregnancy loss before 24 weeks (Table 2).

Pregnancy complications occurred in 45.2\% (238/527). These included gestational diabetes in $15.2 \%$ (80/527), followed by pre-term birth (PTB) in 12.1\% (64/527) and fetal growth restriction (FGR) in 4.4\% (23/527). Pre-eclampsia/ pre-eclampsia-like syndrome was present in $13(2.5 \%)$ women, two of them with severe disease, and a case of HELLP syndrome (haemolysis, elevated liver enzymes and low platelets) with liver ischemia.

Stillbirth occurred in eight $(1.5 \%)$ cases including two cases with confirmed SARS-CoV-2 infection in fetal tissues.

Term delivery was registered in $87.9 \%(463 / 527)$ of pregnancies, $12.1 \%(64 / 527)$ were preterm births accounting for $5.1 \%(27 / 527)$ of cases of spontaneous preterm delivery.

Among 45 cases of SARS-CoV-2 infection before 23 weeks, there were $13(28.9 \%)$, spontaneous miscarriages,

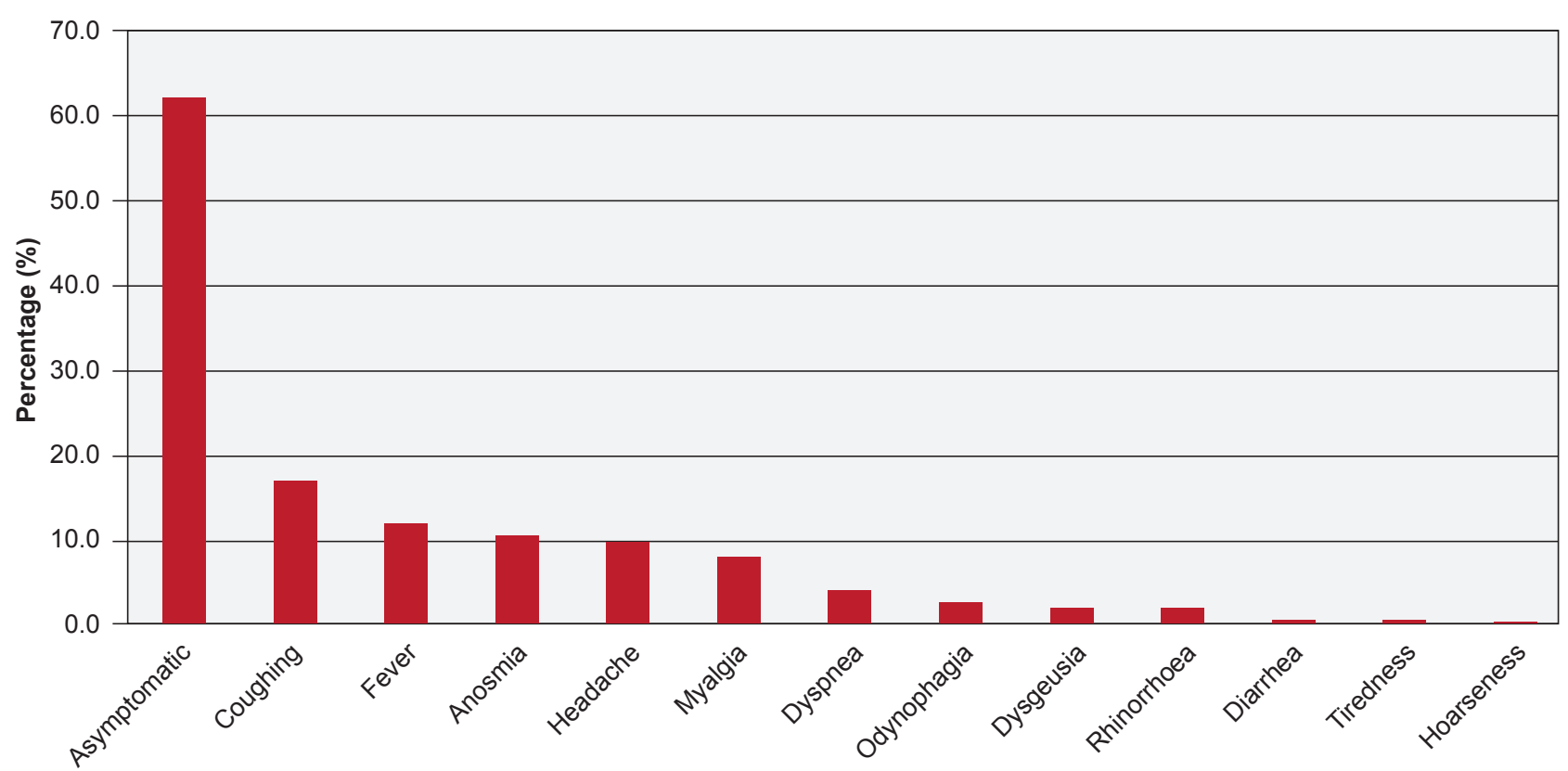

Symptoms

Figure 1 - Symptoms of COVID-19 in pregnant women 
Table 3 - Characteristics of women admitted to ICU

\begin{tabular}{|c|c|}
\hline Characteristics & Values ( $\mathrm{n}$ or $\%$ ) \\
\hline Number of pregnant women admitted & $10(1.6 \%)$ \\
\hline During pregnancy & 8 \\
\hline Postpartum & 2 \\
\hline Mean maternal age, in years, mean $\pm S D$ & $32.3 \pm 4.29$ \\
\hline Gestational age at diagnosis $>33$ weeks & $6(60.0 \%)$ \\
\hline \multicolumn{2}{|l|}{ Comorbidities } \\
\hline No comorbidities & $6(60.0 \%)$ \\
\hline Hypertension & $1(10.0 \%)$ \\
\hline Obesity & $3(30.0 \%)$ \\
\hline Dyslipidaemia & $1(10.0 \%)$ \\
\hline \multicolumn{2}{|l|}{ Symptoms } \\
\hline Dyspnoea & $9(90.0 \%)$ \\
\hline Cough & $8(80.0 \%)$ \\
\hline Fever & $6(60.0 \%)$ \\
\hline Myalgia & $3(30.0 \%)$ \\
\hline Dysgeusia & $1(10.0 \%)$ \\
\hline Headache & $1(10.0 \%)$ \\
\hline Tiredness & $1(10.0 \%)$ \\
\hline Sore throat & $1(10.0 \%)$ \\
\hline \multicolumn{2}{|l|}{ Pregnancy complications } \\
\hline None & $3(30.0 \%)$ \\
\hline Present & $2(20.0 \%)$ \\
\hline Gestational diabetes & $2(20.0 \%)$ \\
\hline Preterm delivery risk & $1(10.0 \%)$ \\
\hline Hydramnios (no diabetes) & $1(10.0 \%)$ \\
\hline \multicolumn{2}{|l|}{ Mode of delivery } \\
\hline Eutocic & $1(10.0 \%)$ \\
\hline Elective caesarean section & $3(30.0 \%)$ \\
\hline Urgent caesarean section & $6(60.0 \%)$ \\
\hline Maternal deaths and stillbirth & None \\
\hline Neonatal outcomes & Values \\
\hline Low birth weight $(<2500 \mathrm{~g})$ & $2(20.0 \%)$ \\
\hline 1-minute Apgar score $\leq 7$ & $2(20.0 \%)$ \\
\hline 5-minute Apgar score $\leq 7$ & $1(10.0 \%)$ \\
\hline SARS-CoV-2 RT-PCR positive test & $0(0.0 \%)$ \\
\hline \multicolumn{2}{|l|}{ Treatment } \\
\hline Hydroxychloroquine & $1(10.0 \%)$ \\
\hline Oxygen & $7(70.0 \%)$ \\
\hline Non-invase ventilation & $1(10.0 \%)$ \\
\hline Invasive ventilation & $2(20.0 \%)$ \\
\hline Azithromycin & $5(50.0 \%)$ \\
\hline Dexamethasone & $1(10.0 \%)$ \\
\hline
\end{tabular}

term delivery occurred in $28(62.2 \%)$ with no complications and four $(8.9 \%)$ had preterm birth. Considering the time of maternal infection (early and late gestation), excluding miscarriages, preterm birth occurred with similar rates $(12.5 \%$ and $12.1 \%$ respectively).

The mode and time of delivery was based on obstetrical reasons in $94.3 \%(497 / 527)$. Spontaneous onset of labour was present in $54.6 \%(288 / 527)$. Eutocic delivery occurred in $43.5 \%$ (229/527), instrumental delivery in 77 cases $(14.6 \%)$ and the caesarean section rate was $41.9 \%$ (221/527) (Table 2).

In terms of indications for caesarean section, $43.4 \%$ (96/221) were due to maternal and fetal indications, fetal distress in $28.5 \%(63 / 221)$ and protracted labour in $28.1 \%$
$(62 / 221)$.

Caesarean section was performed in cases of severe COVID-19 and absence of ideal conditions for induction due to COVID-19 (14 and 13 cases respectively).

When comparing the first and second wave, there was a higher rate of infections reported up to 33 weeks of gestation $[73.4 \%$ vs $26.6 \%$, OR $1.96795 \%$ Cl $(1.305,2.965) p$ $=0.001]$. This was accompanied with a higher risk of cesarean section $[68.5 \%$ vs $31.5 \%$ OR $1.38595 \% \mathrm{Cl}(0.940$, 2.047) $p=0.099$ ] although without statistical significance (Fig. 2). Ongoing pregnancies at the time of the analysis made precluded a comparative analysis during the third wave. 


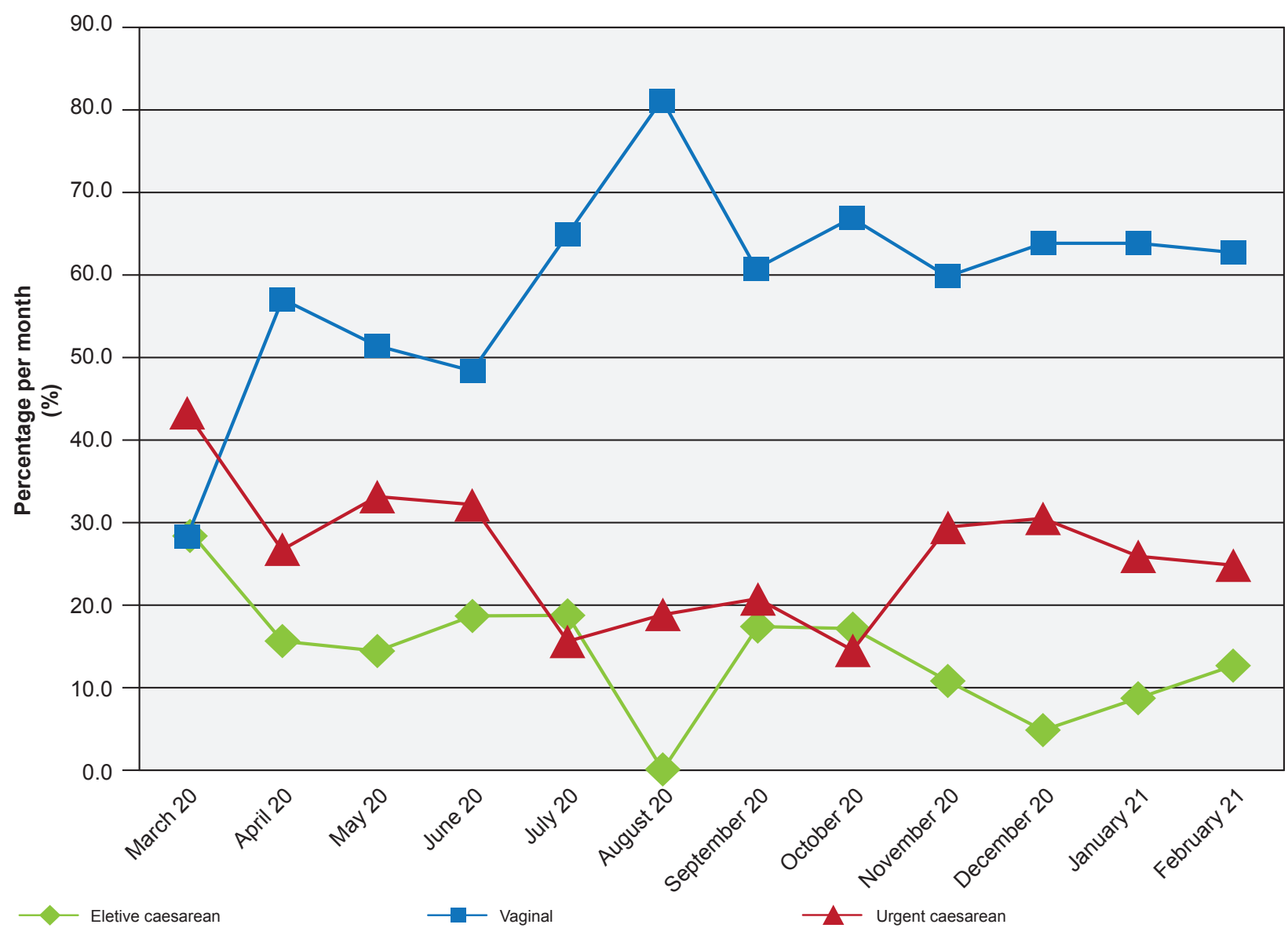

Figure 2 - Mode of delivery/period of time (one-year of the COVID-19 pandemic)

\section{Neonatal outcomes}

From 535 liveborns, there were $7(1.3 \%)$ cases of positive SARS-CoV-2 RT-PCR, confirmed in two sequential nasopharyngeal swab tests between 30 minutes and 48 hours post-partum. Among all neonates, respiratory complications were present in $1.3 \%$ (7/535). Only a neonate required respiratory support during hospital stay and was discharged from the hospital at day 44 with no short-term complications. We report a case of possible fetal inflammatory response syndrome associated with maternal SARS-CoV-2 infection in a PTB at 33 weeks.

The average birth weight was $3102 \pm 622 \mathrm{~g}$ (range 400 - 4805). Small for gestational age [(SGA) $<10^{\text {th }}$ percentile] was found in $9.9 \%(53 / 535)$ of cases and $5.8 \%(31 / 535)$ were classified $<3^{\text {rd }}$ percentile. After adjusting for gestational age and sex, similar results were achieved by using the INTERGROWTH-21 ${ }^{\text {st }}$ and birthweight standard for the Portuguese population calculator.

Four $(0.75 \%)$ neonates had 5-minute Apgar score of $\leq 7$, related with a difficult fetal extraction and fetal distress, one of those requiring neonatal reanimation, two due to prematurity and one due to meconium aspiration (Table 3).

Fetal malformations were described in twelve cases, all of them detected before the reported SARS-CoV-2 infection.

Mother and infant rooming-in was performed in $94.5 \%$
$(500 / 527)$ of cases and $95.0 \%(500 / 527)$ of infants were breastfed.

\section{DISCUSSION}

The nationwide COVID\&PREG registry developed by obstetricians is crucial to follow pregnant women with $\mathrm{CO}-$ VID-19, and thus allowing for a more profound understanding of the impact in pregnancy outcomes.

Universal screening, using SARS-CoV-2 RT-PCR or serological tests, in pregnancy, is very important to determine who was exposed to the disease, to increase knowledge of the implications after the infection during pregnancy and the neonatal period.

Kayem et al showed that severe disease occurred in pregnant women with the highest rates of comorbidities. ${ }^{29}$ In this series, we found similar rates of comorbidities when comparing with previous studies. ${ }^{7-28}$ The most common comorbidities found were obesity, followed by hypertensive disorders:

We found a more severe form of the COVID-19 disease in $2.9 \%$ of pregnant women requiring respiratory support, which is similar to previously reported studies. After 33 weeks of pregnancy, women had more respiratory complications when compared with the first and early second trimester, and that might be associated with physiological changes at this stage. 
It is important to keep women with COVID-19 closely monitored after delivery, as post-partum worsening can occur. There were no maternal deaths in this study, so these outcomes in the Portuguese pregnant population can be reassuring. ${ }^{30}$

It has been proposed that pregnancy loss, preterm premature rupture of membranes (PPROM), preterm birth (PTB) and hypertensive disorders could be related with SARS-CoV-2 infection due to excess of inflammatory response associated with severe SARS. ${ }^{32-32}$

In our study, preterm birth occurred in $12.1 \%$ and SGA was found in $9.9 \%$. In Portugal, the incidence of preterm birth in the last few years is estimated to be around $8.0 \%{ }^{33}$ Our findings, that are similar to those of other reports, suggest that SARS-CoV-2 infected pregnant women have an increased risk of these complications in, and reinforce the aforementioned hypothesis.

In early maternal reported infection in this case series, we found a high rate of spontaneous miscarriage that we cannot rule-out to be associated with COVID-19. Nevertheless, the total number of infections during the first trimester with no immediate complications is unknown so we cannot estimate the impact of SARS-CoV-2 infection in early pregnancy.

Most women were admitted for delivery with term pregnancy. The evidence shows that vertical transmission is unlikely but possible. We also reported one case of stillbirth with proven SARS-CoV-2 fetal infection. This finding concurs with previous reports, where placental infection was documented. ${ }^{7}$

Because the diagnosis of COVID-19 was made at the time of admission in almost all cases of stillbirth, we cannot exclude the influence of SARS-CoV-2 in this outcome.

From the first to the second wave, we noticed a decrease in caesarean section rates in COVID-19 pregnant women. This can reflect a more comprehensive understanding of the virus behaviour and better preparedness for adequate care of COVID-19 patients from the beginning of the pandemic until now. The third wave was not analysed due to the fact that many pregnancies were ongoing.

In our study, $1.7 \%$ of neonates had a positive SARSCoV-2 RT- PCR, which represents a lower percentage when compared with a recent published study by Vouga et al, ${ }^{34}$ where a $2.9 \%$ of neonates had a positive SARS-CoV-2 RT- PCR.

Overall, no major neonatal complications were found, even in neonates with positive SARS-CoV-2 RT-PCR. The benefits of breastfeeding (with possible passive transmission of antibodies for SARS-CoV-2) seems to outweigh any potential risks. An effort should be made to avoid unprotected contact with the neonate. Chen et al, tested breast milk for SARS-CoV-2 and, all six cases that were tested had negative results. ${ }^{35}$ Recently, the presence of SARS-CoV-2 in the breast milk of a COVID-19 positive mother whose neonate also had a positive SARS-CoV-2 diagnostic test has been reported. ${ }^{35}$ In this study, there was a higher percentage of babies that were breastfed. Portuguese guidelines state that parents should be involved in decisions regarding isolation measures or breastfeeding of the newborn.

\section{Strengths and limitations}

This collaborative study, to our knowledge, is one of the first national case series of pregnant women with COVID-19 in Portugal.

Portugal has around 85000 births per year; this sample represents only about $0.8 \%$ births over an eleven-month period. The authors are aware that this series does not reflect the real incidence of COVID-19 in Portuguese pregnant women, as not all cases were included in this collaborative study.

The data has been registered by experienced obstetricians, so data reliability is high. An effort was made to collect a substantial number of cases that occurred in Portugal since the beginning of the COVID-19 pandemic. This series is still small, and findings may not be generalizable to all centres or regions.

Moreover, only short-term neonatal outcomes were available and potential peripartum transmission cannot be overlooked as the incubation period can be long and COVID-19 perinatal data is scarce. Testing for SARS-CoV-2 in biological samples could bring further clarification on this important topic.

As more emerging information regarding vaccination in the pregnant population is increasing, many international guidelines such as the one from the American College of Obstetrics and Gynecology, ${ }^{36}$ Centers for Disease Control and Prevention ${ }^{37}$ and Direção-Geral da Saúde ${ }^{38}$ recommend that pregnant individuals have access to COVID-19 vaccines. The benefits and risks of COVID-19 vaccination in pregnancy should be discussed on an individualised basis. Hopefully, as more pregnant women are getting vaccinated, there will be a reduction in the rate of severe disease, particularly during the third trimester.

\section{CONCLUSION}

SARS-CoV-2 infection in pregnancy may carry increased risks for both pregnant women and the fetuses.

SARS-CoV-2 is an emerging pathogen responsible for one of the greatest pandemics of the last few decades, with a huge impact on worldwide health and economics. Pregnancy and the neonatal period are a major public health concern and the implications in these conditions are still far from being completely understood. The data collection such as in the present study is extremely important to better understand the impact of COVID-19 on pregnancy outcomes, and more studies are needed to understand the implications for mothers in other trimesters of pregnancy. In the future, other methods of diagnosis, such as serological tests, and the widespread implementation of SARS-CoV-2 immunization in pregnancy, could change the paradigm of the infection in pregnancy.

\section{AUTHORS CONTRIBUTION}

NC: Elaboration of the national registry of COVID-19 
and pregnancy. Associate investigator on COVID\&PREG study. Insertion of new cases in the registry. Statistics evaluation of the registry results. Writing of the manuscript and subsequent improvement based on reviewers' evaluation.

CCS, MCA, MG, MO, ML, MFF, IR, BF, IM, CS, MJA, PP, MM, DG, AB, AF, GA, VS, FC, MC, CF, MB, MS: Insertion of new cases in the registry. Improvement based on reviewers' evaluation.

HC: Approvement of the national registry: Base de dados nacional de gravidez e COVID-19 (COVID\&PREG) in CHRC (Comprehensive Health Research Centre) - NMS unit. Improvement based on reviewers' evaluation.

AC: Elaboration of the national registry of COVID-19 and pregnancy. Principal investigator on COVID\&PREG study. Writing of the manuscript and subsequent improvement based on reviewers' evaluation.

MJA: Elaboration of the national registry of COVID-19 and pregnancy. Associate investigator on COVID\&PREG study. Improvement based on reviewers' evaluation.

$A Q$ : Elaboration of the national registry of COVID-19 and pregnancy. Statistics evaluation of the registry results. Insertion of new cases in the registry. Writing of the manuscript and subsequent improvement based on reviewers' evaluation. Associate investigator on COVID\&PREG study.

\section{REFERENCES}

1. Direção Geral da Saúde. Orientação: SARS-CoV-2; COVID-19; Gravidez; Parto; Maternidade; 04/2021; [cited 2021 Jul 19]. Available from: https://covid19.min-saude.pt/dgs-atualiza-orientacao-sobregravidez-e-parto/.

2. Lyra J, Valente R, Rosário M, Guimarães $M$. Cesarean section in a pregnant woman with COVID-19: first case in Portugal. Acta Med Port. 2020;33:429-31.

3. Baud D, Gianonni E, Pomar L, Qi X, Nielsen-Saines K, Musso D, et al. COVID-19 in pregnant women. Lancet Infect Dis. 2020;20:654.

4. Hantoushzadeh S, Shamshirsaz A, Aleyasin A, Seferovic M; Aski S, Arian S, et al. Maternal death due to COVID-19. Am J Obstet Gynecol. 2020;223:109.e1-16.

5. Ahmed I, Azhar A, Eltaweel N, Tan B. First Covid-19 maternal mortality in the UK associated with thrombotic complications. $\mathrm{Br} \mathrm{J}$ Haematol. 2020;190:e37-8.

6. Lumbreras-Marquez $M$, Campos-Zamora $M$, Leon $H$, Farber $M$. Maternal mortality from COVID-19 in Mexico. Int J Gynaecol Obstet. 2020;150:266-7.

7. Khalil A, Kalafat E, Benlioglua C, O'Briend P, Morris E, Draycottd T, et al. SARS-CoV-2 infection in pregnancy: a systematic review and metaanalysis of clinical features and pregnancy outcomes, EclinicalMedicine. 2020;25:100446

8. Mullins E, Hudak M, Banerjee J, Getzlaff T, Townson J, Barnette K, et al. Pregnancy and neonatal outcomes of COVID-19 - coreporting of common outcomes from the PAN-COVID and AAP SONPM registry. Ultrasound Obstet Gynecol. 2021;57:573-81.

9. Prabhu M, Cagino K, Matthews K, Friedlander R, Glynn S, Kubiak $\mathrm{J}$, et al. Pregnancy and postpartum outcomes in a universally tested population for SARSCoV-2 in New York City: a prospective cohort study. BJOG. 2020;127:1548-56.

10. Baud D, Greub G, Favre G, Gengler C, Jaton k, Dubruc E, et al. Secondtrimester miscarriage in a pregnant woman with SARSCoV2. JAMA. 2020;323:2198-200.

11. Patanè L, Morotti D, Giunta M. Vertical transmission of COVID-19: SARS-CoV-2 RNA on the fetal side of the placenta in pregnancies with COVID-19 positive mothers and neonates at birth. Am J Obstet Gynecol. 2020;2:1-4.

12. Hosier H, Farhadian S, Morotti R, Deshmukh U, Lu-Culligan A, Campbell K, et al. SARS-CoV-2 infection of the placenta. J Clin Invest. 2020;130:4947-53.

\section{PROTECTION OF HUMANS AND ANIMALS}

The authors declare that the procedures were followed according to the regulations established by the Clinical Research and Ethics Committee and to the 2013 Helsinki Declaration of the World Medical Association.

\section{DATA CONFIDENTIALITY}

The authors declare having followed the protocols in use at their working center regarding patients' data publication.

\section{COMPETING INTERESTS}

The authors have no competing interests, or other interests that might be perceived to influence the results and/or discussion reported in this paper.

\section{FUNDING SOURCES}

This research received no specific grant from any funding agency in the public, commercial, or not-for-profit sectors.

13. Vivanti A, Vauloup-Fellous C, Prevot S, Zupan V, Suffee C, Cao J, et al. Transplacental transmission of SARS-CoV-2 infection. Nat Commun. 2020;11:1-7

14. Sheth S, Shah N, Bhandari V. Outcomes in COVID-19 positive neonates and possibility of viral vertical transmission: a narrative review. Am J Perinatol. 2020;37:1208-16.

15. Prakesh S, Diambomba Y, Acharya G, Morris S, Bitnun A. Classification system and case definition for SARS-CoV-2 infection in pregnant women, fetuses, and neonates. Acta Obstet Gynecol Scand. 2020;99:565-8.

16. Deemah Salem D, Katranji F, Bakdash T. COVID-19 infection in pregnant women: review of maternal and fetal outcomes. Int J Gynaecol Obstet. 2021;152:291-8

17. Burki T. Understanding variants of SARS-CoV-2. Lancet. 2021:397:462.

18. Instituto Nacional de Saúde Doutor Ricardo Jorge. Diversidade genética do novo coronavírus SARS-CoV-2 (COVID-19) em Portugal- Relatório de situação. Lisboa: INSA; 2021.

19. Royal College of Obstetricians \& Gynaecologists. Coronavirus (COVID-19) infection and pregnancy. Version 14.2. [cited $2021 \mathrm{Apr} 20$ ] Available from: https://www.rcog.org.uk/coronavirus-pregnancy.

20. Mahase E. Covid-19: Hospital admission $50-70 \%$ less likely with omicron than delta, but transmission a major concern. BMJ. 2021;375:n3151.

21. Direção Geral da Saúde. COVID-19: fase de mitigação gravidez e parto. Orientação nº18/2020. Lisboa: DGS; 2020.

22. Sutton D, Fuchs K, D'Alton M, Goffman D. Universal screening for SARSCoV-2 in women admitted for delivery. N Engl J Med. 2020;382:2163-4.

23. Dória $M$, Peixinho $C$, Laranjo $M$, Mesquita Varejão $A$, Silva PT. Covid-19 during pregnancy: a case series from an universally tested population from the north of Portugal. Eur J Obstet Gynecol Reprod Biol. 2020;250:261-2.

24. Intergrowth 21. Standards and tools. [cited $2021 \mathrm{Jul} 19$ ]. Available from: https://intergrowth21.tghn.org/standards-tools/.

25. Sousa-Santos R, Miguelote R, Cruz-Correia R, Santos C, Bernardes J. Development of a birthweight standard and comparison with currently used standards. What is a 10th centile? Eur J Obstet Gynecol. 2016;206:184-94.

26. Knight M, Bunch K, Vousden N, Morris E, Simpson N, Gale C, et al. Characteristics and outcomes of pregnant women admitted to hospital with confirmed SARS-CoV-2 infection in UK: national population-based cohort study. BMJ. 2020;369:m2107.

27. Yan J, Juanjuan G, Fan C, Juan J, Yu X, Li J, et al. Coronavirus disease 
2019 (COVID-19) in pregnant women: a report based on 116 cases. Am J Obstet Gynecol. 2020;223:e111-4.

28. Smith V, Seo D, Warty R, Payne O, Salih M, Chin K, et al. Maternal and neonatal outcomes associated with COVID-19 infection: a systematic review. PLoS One. 2020;15:e0234187.

29. Kayem G, Lecarpentier E, Deruelle P, Bretelle F, Azria E, Blanc J, et al. A snapshot of the Covid-19 pandemic among pregnant women in France. J Gynecol Obstet Hum. 2020;49:101826.

30. Youssef A, Serra C, Pilu G. Lung ultrasound in the coronavirus disease 2019 pandemic: a practical guide for obstetricians and gynaecologists. Am J Obstet Gynecol. 2020;223:128-31.

31. Lam CM, Wong SF, Leung T, Chow K, Yu W, Wong T, et al. A case controlled study comparing clinical course and outcomes of pregnant and non-pregnant women with severe acute respiratory syndrome. BJOG. 2004;111:771-4

32. Wong SF, Chow KM, Leung T, Ng W, Ng T, Shek C, et al. Pregnancy and perinatal outcomes of women with severe acute respiratory syndrome. Am J Obstet Gynecol. 2004;191:292-7.

33. Instituto Nacional de Estatística. Estatísticas demográficas. Lisboa: INE; 2019.

34. Vouga M, Favre G, Martinez-Perez O, Pomar L, Acebal L, Abascal-Saiz
A, et al. Maternal outcomes and risk factors for COVID-19 severity among pregnant women. Sci Rep. 2021;11:13898.

35. Chen H, Guo J, Wang C, Luo F, Yu X, Zhang W, et al. Clinical characteristics and intrauterine vertical transmission potential of COVID-19 infection in nine pregnant women: a retrospective review of medical records. Lancet. 2020;395:809-15.

36. American College of Obstetricians and Gynecologists. COVID-19 vaccination considerations for obstetric-gynecologic care. Practice advisory, Dec 2020 updated Jul 2021. [cited 2021 Dec 03]. Available from: https://www.acog.org/clinical/clinical-guidance/practice-advisory/ articles/2020/12/covid-19-vaccination-considerations-for-obstetricgynecologic-care.

37. Centers for Disease Control and Prevention. Interim Clinica Considerations for use of COVID-19 vaccines currently authorized in the United States. May 2021, updated Jul 2021. [cited 2021 Dec 23]. Available from: https://www.cdc.gov/vaccines/covid-19/clinicalconsiderations/covid-19-vaccines-us.html.

38. Direção Geral da Saúde. Orientação: Campanha de vacinação contra a COVID-19; 01/2021; atualizado em 07/2021. [cited 2021 Jul 19]. Available from: https://covid19.min-saude.pt/normas/. 